\title{
Carbon and nitrogen limitation of soil microbial respiration in a High Arctic successional glacier foreland near Ny-Ålesund, Svalbard
}

\author{
Shinpei Yoshitake, ${ }^{1}$ Masaki Uchida, ${ }^{2}$ Hiroshi Koizumi ${ }^{3}$ \& Takayuki Nakatsubo ${ }^{4}$ \\ 1 Graduate School of Biosphere Science, Hiroshima University, Japan \\ 2 National Institute of Polar Research, 9-10, Kaga 1-chome, Itabashi-ku, Tokyo, 173-851 Japan \\ 3 Institute for Basin Ecosystem Studies, Gifu University, Gifu, 501-1193 Japan \\ 4 Graduate School of Biosphere Science, Hiroshima University, 7-1 Kagamiyama 1-chome, Higashi-Hiroshima, 739-8521 Japan
}

\section{Keywords}

High Arctic; microbial biomass; microbial

respiration; PLFA; primary succession;

substrate limitation.

Correspondence

Shinpei Yoshitake, Graduate School of Biosphere Science, Hiroshima University,

7-1 Kagamiyama 1-chome, Higashi-Hiroshima, 739-8521, Japan. Email:

synp@hirashima-u.ac.jp

doi:10.1111/j.1751-8369.2007.00001.x

\begin{abstract}
The hypotheses that carbon and nitrogen availability limit microbial activity, and that the key factors limiting microbes vary along the successional gradient were tested in a High Arctic glacier foreland. We examined the responses of the respiration rate and the phospholipid fatty acid content to the addition of carbon and/or nitrogen. Soil samples were collected from the early stage and late stage of primary succession in the foreland of a glacier near Ny-Ålesund, Svalbard. The addition of both carbon (glucose) and nitrogen (ammonium nitrate) engendered an increase in the microbial respiration rate in the early stage of succession. In contrast, the addition of either carbon or nitrogen did not increase the microbial respiration rate. In the late stage of succession the addition of carbon alone, as well as the addition of both carbon and nitrogen, increased the microbial respiration rate. However, neither the addition of carbon nor the addition of nitrogen affected the total phospholipid fatty acid content (an index of microbial biomass) for any soil within 15 days of incubation at $10^{\circ} \mathrm{C}$. An increase in the respiration rate was therefore attributed to changes in the physiological activities of the microbial community, such as enzymatic activity. Our study suggests that microbial respiration was limited by the low availability of both carbon and nitrogen in the early stage of succession. Thereafter, nitrogen limitation is mitigated.
\end{abstract}

Glacial retreat exposes new ground surfaces and provides plants and microorganisms with new habitats. In the High Arctic, plant colonization takes place very slowly because it is restricted by severe environmental factors including low temperatures, a short growing season, low moisture and nutrient availability, and unstable soil structure (e.g., cryoturbation) (Hodkinson et al. 2003). We can therefore observe various plant communities ranging from pioneer to later successional species along a primary successional gradient within a glacier foreland. Successional changes of vegetation after glacial retreat in High Arctic regions, and their relation to environmental conditions, have been studied by many ecologists (e.g., Svoboda \& Henry 1987; Minami \& Kanda 1995; Hodkinson et al. 2003; Jones \& Henry 2003; Okitsu et al. 2004).
In contrast, little information exists about soil microorganisms in a High Arctic glacier foreland. Soil microorganisms are known to play an important role in soil formation, and therefore in the progress of primary succession through the decomposition and mineralization of organic matter (Jenkinson \& Ladd 1981). Additionally, their function as a source and a sink of labile carbon and nutrients is of great importance (Jenkinson \& Ladd 1981). A few studies conducted in the High Arctic have shown that the microbial respiration rate and biomass are generally low in the early stages of succession and tend to increase with the progress of succession (Bekku et al. 1999; Bekku, Kume et al. 2004; Bekku, Nakatsubo et al. 2004; Yoshitake et al. 2006). These findings suggest that some environmental factors limit soil microbial activity and growth in the early stages of succession. 
Previous studies have shown that substrate deficiencies (especially of carbon and nitrogen) often limit microbial activity and growth in many ecosystems, including forests (Joergensen \& Scheu 1999; Vance \& Chapin III 2001; Ekblad \& Nordgren 2002; Allen \& Schlesinger 2004), agricultural land (Marschner et al. 2003; Teklay et al. 2006), dry desert (Schaeffer et al. 2003) and solfatara fields (Yoshitake et al. 2007). The extent of this limitation apparently varies with ecosystem development. For example, Aikio et al. (2000) examined the changes in soil and microbial properties in the primary succession on a post-glacial land uplift island in Finland. They reported that soil microbes became increasingly nitrogen limited during the succession. This shift in limiting factors was partly explained by changes in the quality of the detritus; a higher carbon/nitrogen $(\mathrm{C} / \mathrm{N})$ ratio of the detritus was found in late stages of succession (Aikio et al. 2000). Yoshitake et al. (2007), who tested the substrate limitation of microbial activity and growth by amendment experiments in an acidic solfatara field, also described the shift in limiting factors with ecosystem development; microbial activity and growth were shifted from carbon- and nitrogen-limited to carbon-limited.

In the High Arctic, the quality and quantity of organic matter and, therefore, the availability of carbon and nitrogen are expected to be different for the early and late stages of primary succession, because it is known that the composition and the coverage of vegetation varies with succession (e.g., Hodkinson et al. 2003; Jones \& Henry 2003; Okitsu et al. 2004), and that plant species differ in leaf and litter quality (Osono et al. 2006). Therefore, it is likely that soil microorganisms are also limited by the availability of carbon and nitrogen in the early stages of succession in High Arctic glacier forelands.

For this study, we hypothesized that the availability of carbon and nitrogen limit microbial activity, and that key factors limiting microbes vary along the successional gradient in High Arctic glacier forelands. To test these hypotheses we examined respiration rates in both the early and late stages of primary succession in a glacier foreland in Svalbard, and studied the responses of the respiration rates to changes in the levels of carbon and nitrogen. The phospholipid fatty acid (PLFA) content, an index of microbial biomass and community structure, was also investigated to elucidate the relationship between PLFA content and the respiration rate.

\section{Materials and methods}

\section{Study site}

This study was conducted at the front of Austre Brøggerbreen (East Brøgger Glacier) in Ny-Ålesund, north-

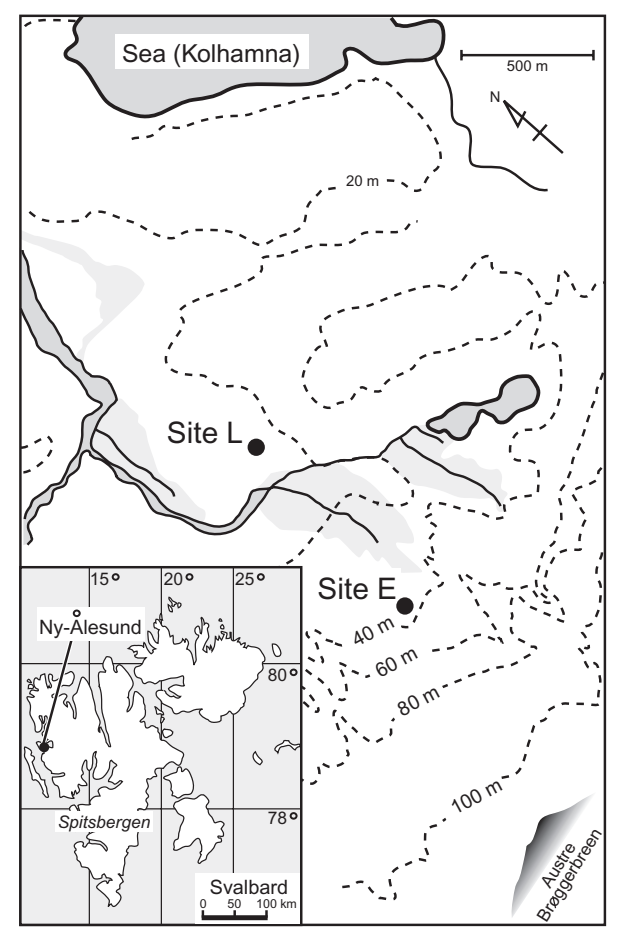

Figure 1 Study sites in Ny-Ålesund, Svalbard (modified from Nakatsubo et al. 1998).

western Spitsbergen, Svalbard $\left(79^{\circ} \mathrm{N}, 12^{\circ} \mathrm{E}\right.$; Fig. 1). For the period 1995-98, the annual mean air temperature was $-5.5^{\circ} \mathrm{C}$ and the level of precipitation was $362 \mathrm{~mm}$ in this area (data from the Norwegian Meteorological Institute; see Uchida et al. 2002 for details).

In this study, sites E and L were set up as the early and late stages of succession, respectively (Fig. 1). Sites E and $\mathrm{L}$ in this study were identical to sites 1 and 3 in some previous studies (Nakatsubo et al. 1998; Bekku et al. 1999; Nakatsubo et al. 2005). Site E was located on a newly deglaciated moraine near the tip of Austre Brøggerbreen. The precise chronological age of vegetation is unknown because of unpredictable disturbances in the forelands of glaciers in this area (Hodkinson et al. 2003). The age of Site L, roughly estimated based on geographical information, was hundreds of years or more (Kume et al. 1999; Bekku, Kume et al. 2004).

At site E, plant colonization was very limited and was restricted to isolated small plants, such as Saxifraga oppositifolia L. The coverage of vascular plants was very low $(<1 \%)$, but black soil crusts (soil surface communities consisting of algae, cyanobacteria and lichen) partially covered the ground. The ground at site L was patterned with small polygons. A mixed community of bryophytes (mainly Sanionia uncinata [Hedw.] Loeske, Hylocomium splendens [Hedw.] Schimp and Aulacomnium turgidum 
[Wahlenb.] Schwaegr.) and vascular plants (mainly Salix polaris Wahlenb., Luzula confusa Lindeb. and Poa alpina L.) covered the marginal area of the polygons, whereas the central area of the polygons consisted almost entirely of bare ground. A mixed community of bryophytes and vascular plants covered about $53 \%$ of the ground, and black soil crusts covered about $30 \%$ of the ground. The remaining $17 \%$ was bare ground. A more detailed description of the vegetation at these sites is available in previous reports (Nakatsubo et al. 1998; Nakatsubo et al. 2005).

\section{Soil sampling}

Soil samples were collected from five points $(10 \mathrm{~cm} \times 20 \mathrm{~cm})$ at each site in late June 2005. At site E, black soil crusts were removed with a knife and the mineral soil of the $0-5 \mathrm{~cm}$ layer was sampled. At site L, the parts of vascular plants and green moss standing above ground were cut and removed using scissors, then the organic soil layer (FH layer, $2.2 \pm 0.5 \mathrm{~cm}$ thick) and mineral soil of the $0-5 \mathrm{~cm}$ layer (under the $\mathrm{FH}$ layer) were collected. Plant roots and gravel in these samples were removed using a 4 -mm mesh sieve and tweezers. These soil samples were stored at $4^{\circ} \mathrm{C}$ for up to 10 days after sampling until the amendment experiments were carried out.

Some soil properties are summarized in Table 1. For this study, the water holding capacity (WHC) was deter- mined according to the definition by Paul et al. (1999), which was the gravimetric water content of sieved soil that had been saturated and allowed to drain in a filter. The total carbon and nitrogen contents of the soil were measured using a CN analyser (2400 II; PerkinElmer Inc., Wellesley, MA, USA) and the $\mathrm{C} / \mathrm{N}$ ratio was calculated. At site $\mathrm{E}$, a remarkably high $\mathrm{C} / \mathrm{N}$ ratio was observed $(\mathrm{C} / \mathrm{N}=123)$ because alkaline soil at this site includes carbonates (Uchida et al. unpubl. data).

\section{Changes in microbial respiration after the addition of carbon and nitrogen}

The respiration rates after the addition of either a carbon (glucose) or a nitrogen (ammonium nitrate) source, or both, were measured for 15 days (measurements were made on days $0,2,5,10$ and 15) to determine whether the availability of either carbon or nitrogen limits microbial respiration. We allocated five subsamples of the three soils (mineral soil of site E, and mineral and organic soils from site L) to each of four treatments: $\mathrm{C}+$, the addition of a source of carbon; $\mathrm{N}+$, the addition of a source of nitrogen; $\mathrm{CN}+$, the addition of both a source of carbon and a source of nitrogen; and a control. A soil sample equivalent to $5 \mathrm{~g}$, or 20-30 g dry weight for organic and mineral soils, was placed in a cylindrical plastic case $(9 \mathrm{~cm}$ in diameter and $2.5 \mathrm{~cm}$ in height). In the $\mathrm{C}+$ treatment, $10 \mathrm{mg}$ of glucose was added for each gram of dry soil (4 $\mathrm{mg} \mathrm{C} \mathrm{g}^{-1}$ dry soil). Soils in the $\mathrm{N}+$ treatment received

Table 1 Soil characteristics in the sites studied. Values are means $( \pm$ SE) for five replications $(n=5)$. In each row values followed by the same capital letter are not significantly different (Tukey-Kramer test, $P>0.05$ ).

\begin{tabular}{|c|c|c|c|}
\hline \multirow{2}{*}{$\begin{array}{l}\text { Site } \\
\text { Soil layer }\end{array}$} & \multirow{2}{*}{$\begin{array}{l}\text { Site E } \\
\text { Mineral }\end{array}$} & \multicolumn{2}{|l|}{ Site L } \\
\hline & & Organic & Mineral \\
\hline $\mathrm{pH}\left(\mathrm{H}_{2} \mathrm{O}\right)^{\mathrm{a}}$ & $8.3(0.08)^{A}$ & $6.2(0.03)^{B}$ & $6.1(0.04)^{B}$ \\
\hline Water content ${ }^{b}$ & $0.20(0.03)^{A}$ & $1.46(0.16)^{\mathrm{B}}$ & $0.39(0.02)^{\mathrm{A}}$ \\
\hline Water holding capacity $(\mathrm{WHC})^{\mathrm{b}, \mathrm{c}}$ & $0.35(0.02)^{A}$ & $5.36(0.90)^{\mathrm{B}}$ & $0.89(0.06)^{A}$ \\
\hline Organic matter content (mg g ${ }^{-1}$ dry soil) ${ }^{d}$ & $12(2)^{\mathrm{A}}$ & $377(19)^{\mathrm{C}}$ & $138(11)^{\mathrm{B}}$ \\
\hline Total carbon (mg g ${ }^{-1}$ dry soil) $)^{\mathrm{e}}$ & $14.3(1.0)^{\mathrm{A}}$ & $215.0(30.8)^{B}$ & $66.1(5.1)^{\mathrm{A}}$ \\
\hline Total nitrogen (mg g ${ }^{-1}$ dry soil) $^{\mathrm{e}}$ & $0.12(0.01)^{A}$ & $9.34(1.01)^{\mathrm{C}}$ & $2.82(0.17)^{\mathrm{B}}$ \\
\hline $\mathrm{C} / \mathrm{N}$ ratio & $123(13)^{A}$ & $23(2)^{\mathrm{B}}$ & $23(1)^{\mathrm{B}}$ \\
\hline Available phosphorus (mg g ${ }^{-1}$ dry soil) ${ }^{f}$ & $0.9(0.1)^{A}$ & $17.1(0.7)^{B}$ & $3.4(0.7)^{\mathrm{A}}$ \\
\hline Soil temperature $\left({ }^{\circ} \mathrm{C}\right)$, mean $(\min .-\max .)^{g}$ & $-2.2(-16.3-17.9)$ & N.D. & $-3.0(-13.3-17.8)$ \\
\hline Dominant vegetation & $\begin{array}{l}\text { Black soil crust } \\
\text { (Cryptogamic crust) }\end{array}$ & $\begin{array}{l}\text { Moss (Sanionia uncinata), } \\
\text { Salix polaris }\end{array}$ & \\
\hline
\end{tabular}

Water : soil (air-dried) $=5: 1$

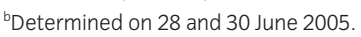

${ }^{c}$ According to Paul et al. (1999).

${ }^{\mathrm{d}}$ Determined by loss in weight on ignition $\left(550^{\circ} \mathrm{C}, 12 \mathrm{~h}\right)$.

${ }^{e}$ Measured with a CN analyser (2400 II, PerkinElmer Inc., Wellesley, MA, USA).

${ }^{f}$ According to Olsen \& Sommers (1982).

${ }^{\mathrm{g}}$ Measured at a depth of $2 \mathrm{~cm}$ from 1 January to 31 December 2004.

N.D., not determined. 
$1.1 \mathrm{mg}$ of ammonium nitrate for each $1 \mathrm{~g}$ of dry soil (0.4 $\mathrm{mg} \mathrm{N} \mathrm{g}^{-1}$ dry soil). In the $\mathrm{CN}+$ treatment, both glucose and ammonium nitrate were added to the soil (4 mg C $+0.4 \mathrm{mg} \mathrm{N} \mathrm{g}^{-1}$ dry soil). Glucose and ammonium nitrate were added to the soils in enough water to achieve the desired water content $(60 \%$ WHC). For soil samples from site E, however, glucose, ammonium nitrate and water were added directly to the soil samples and mixed immediately; these soils had low WHC and their initial water content (57\% WHC; Table 1) was near the desired water content $(60 \%$ WHC). Soils supplied only with water served as controls. All soil samples were incubated in a room where the air temperature was similar to that of field conditions $\left(9.7 \pm 4.7^{\circ} \mathrm{C}\right)$.

The soil respiration rates (taken as $\mathrm{CO}_{2}$ emission rates) of samples were measured at $10 \pm 0.3^{\circ} \mathrm{C}$ using an openflow system with an infrared gas analyser (IRGA; LI6262; Li-Cor Inc., Lincoln, NE, USA). A detailed description of this system appeared in Bekku et al. (1997). The plastic case with the sample was placed in a cylindrical chamber $(9.2 \mathrm{~cm}$ in diameter and $3 \mathrm{~cm}$ in height) that was connected to the system. Ambient air containing 370-385 ppm $\mathrm{CO}_{2}$ was pumped into the system at a suitable flow rate (either 100 or $300 \mathrm{ml} \mathrm{min}^{-1}$ ), depending on the quantity of $\mathrm{CO}_{2}$ released from the sample. During the measurement the chamber was placed in a water bath to control the temperature.

\section{Changes in PLFA contents after the addition of carbon and nitrogen}

The soil PLFA contents before and after the addition of either a carbon source (glucose) or a nitrogen source (ammonium nitrate), or both, were also determined to elucidate whether the availability of carbon and nitrogen affects the microbial biomass and community structure. The experimental design was almost identical to that for the respiration measurement (described above); PLFA analyses were made on the samples on days 2, 10 and 15 after the addition of carbon and/or nitrogen sources.

Soil samples were freeze-dried, brought to Japan, and stored at $-80^{\circ} \mathrm{C}$ until analysis. Lipids were extracted using the method of Bligh \& Dyer (1959), as modified by White et al. (1979) and Frostegård et al. (1991). Briefly, 1-2 g (dry weight) of soil was extracted using a chloroform methanol citrate buffer mixture ( $1: 2: 0.8)$. The lipids were separated into neutral lipids, glycolipids and phospholipids on a silicic acid column (Sep-Pak ${ }^{\mathrm{TM}}$ plus silica; Waters Corp., Milford, MA, USA) (Arao et al. 2001). The phospholipids were esterified with HCl-methanol Reagent (Tokyo Kasei Kogyo Co. Ltd., Tokyo, Japan) (Stoffel et al. 1959). The resultant fatty-acid methyl esters were separated using a gas chromatograph/mass spectrometer (GC-17A/GCMS-QP5000; Shimadzu Corp., Kyoto, Japan) equipped with a capillary column (PhenylMethyl/Silicone (30 m DB-5 ms); J\&W Scientific Inc., Folsom, CA, USA). Helium was used as the carrier gas. Peak areas were quantified by adding methyl nonadecanoate fatty acid (19:0) as an internal standard. The fatty acid nomenclature used was as described by Frostegård et al. (1993). The total content of PLFAs (TotPLFAs) was used to indicate the total microbial biomass (Frostegård et al. 1993). We use the PLFA composition as an index of microbial community structure because phospholipids are good indicators of the composition of living soil microbes (White et al. 1979). The PLFAs are classifiable into several categories according to their molecular structure (see Peacock et al. 2001; Yoshitake et al. 2006). In this study, PLFAs were classified into four categories (straight chain saturated fatty acids, branched chain fatty acids including cyclopropane fatty acids, unsaturated

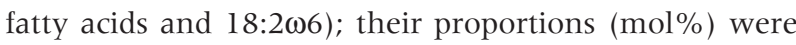
summed. The content of 18:206 is known to be an indicator of fungal biomass (Federle et al. 1986). Previous studies have shown that this classification is useful for analyses of the shift in the microbial community structure (Yoshitake et al. 2006).

\section{Statistical analysis}

We used a repeated measures two-way ANOVA with carbon and nitrogen as factors, and with time as the repeated factor, to test the effects of the addition of carbon and/or nitrogen on microbial respiration rates and PLFA contents. We used the Tukey-Kramer test for multiple comparisons for each day. Significance was inferred in cases where $P<0.05$.

\section{Results}

\section{Changes in microbial respiration after the addition of carbon and nitrogen}

For all soil samples, the respiration rate of soils with no changes (control) did not change significantly throughout the incubation period (one-way ANOVA; $P>0.05$; Fig. 2). The respiration rate on day 0 in the early stage of succession (site E) was $1.0 \mu \mathrm{g} \mathrm{CO}_{2}-\mathrm{C} \mathrm{g}^{-1} \mathrm{~h}^{-1}$, which was almost one half of the respiration rate measured in mineral soil of the late stage of succession (site $\mathrm{L}, 1.8 \mu \mathrm{g} \mathrm{CO}_{2}-$ $\left.\mathrm{C}^{-1} \mathrm{~h}^{-1}\right)$. Organic soil from site $\mathrm{L}$ had a remarkably high respiration rate $\left(16.7 \mu \mathrm{g} \mathrm{CO}_{2}-\mathrm{C} \mathrm{g}^{-1} \mathrm{~h}^{-1}\right)$.

In site $\mathrm{E}$, neither the addition of carbon $(\mathrm{C}+)$ nor the addition of nitrogen $(\mathrm{N}+)$ increased the microbial respiration rate significantly (Tukey-Kramer test, $P>0.05$; Fig. 2a). In contrast, the respiration rates of soils with the 

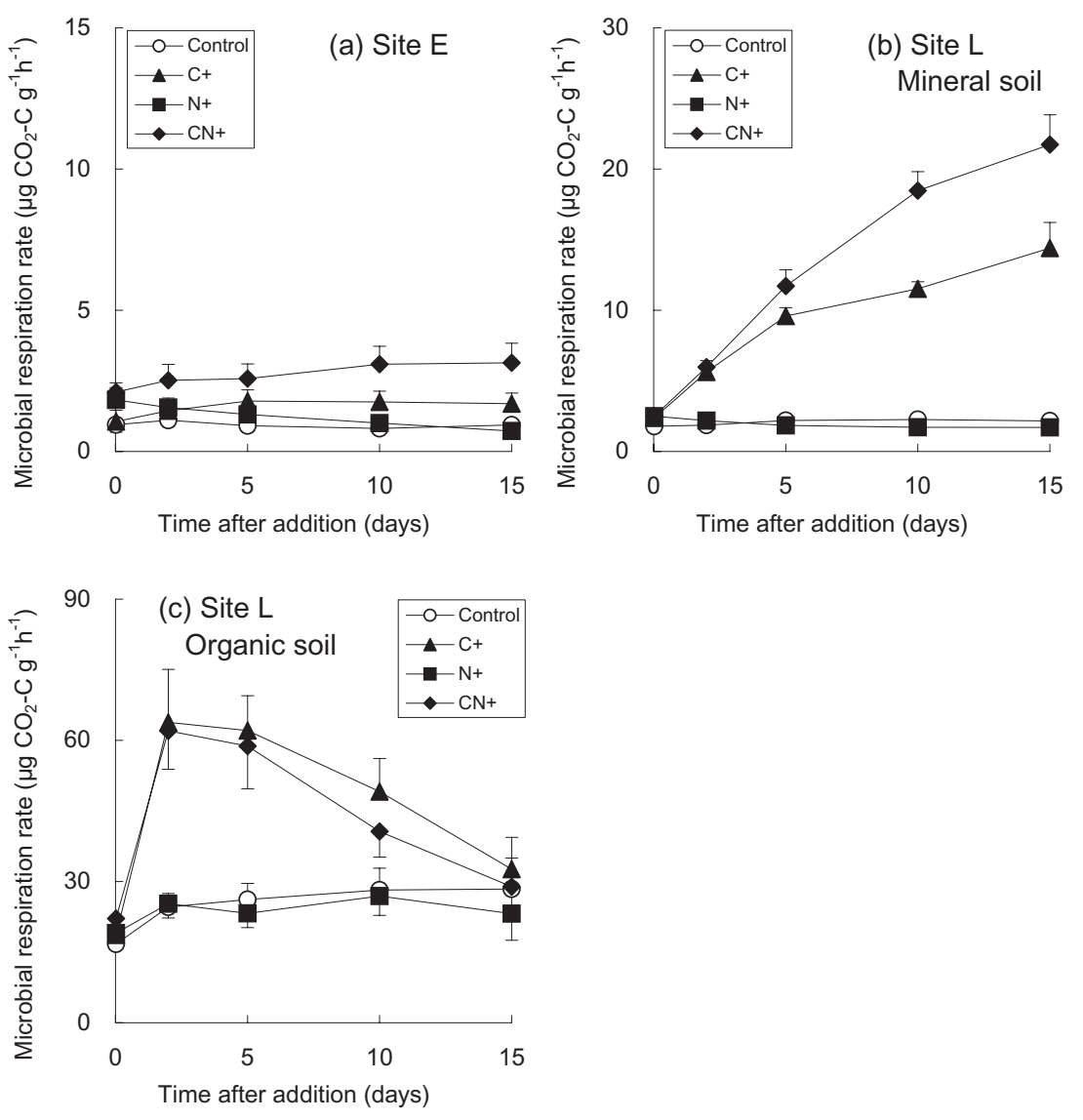

Figure 2 Effects of the addition of glucose $(\mathrm{C}+)$ and ammonium nitrate $(\mathrm{N}+)$ on the soil microbial respiration rate of (a) site $E$, (b) mineral soil from site $L$ and (c) organic soil from site $L$. Vertical bars represent \pm SE $(n=5)$.

addition of both carbon and nitrogen $(\mathrm{CN}+)$ increased significantly (Tukey-Kramer test, $P<0.05$ ) after day 5; its highest rate was $3.1 \mu \mathrm{g} \mathrm{CO}_{2}-\mathrm{C} \mathrm{g}^{-1} \mathrm{~h}^{-1}$.

In the mineral soil of site $\mathrm{L}$, the respiration rate of soils with glucose $(\mathrm{C}+$ and $\mathrm{CN}+)$ increased continuously (Fig. 2b). The highest respiration rate of soil with glucose added $\left(14.4 \mu \mathrm{g} \mathrm{CO}_{2}-\mathrm{C} \mathrm{g}^{-1} \mathrm{~h}^{-1}\right)$ was almost seven times that of the control (Tukey-Kramer test, $P<0.05$; Fig. 2b). The addition of both carbon and nitrogen $(\mathrm{CN}+)$ caused a great increase in the respiration rate, with a maximum rate of $21.7 \mu \mathrm{g} \mathrm{CO}_{2}-\mathrm{C} \mathrm{g}^{-1} \mathrm{~h}^{-1}$ on day 15 , which was almost 10 times that of the control respiration rate (TukeyKramer test, $P<0.05)$. A significant interaction was apparent for the addition of carbon and the addition of nitrogen (repeated measures two-way ANOVA, $P<0.05$ ).

The response of microbial respiration to the added materials was much faster in the organic soil of site L (Fig. 2c). On day 2, the respiration rate of soils with glucose added ( $\mathrm{C}+$ and $\mathrm{CN}+$ ) had already reached 62.0$63.8 \mu \mathrm{g} \mathrm{CO}_{2}-\mathrm{C} \mathrm{g}^{-1} \mathrm{~h}^{-1}$, which was almost three times that of the control (Tukey-Kramer test, $P<0.05$ ). However, in both the $\mathrm{C}+$ and $\mathrm{CN}+$ treatments, the respiration rate decreased gradually and no significant differences among treatments were detected on day 15 (Tukey-Kramer test, $P>0.05)$. The addition of nitrogen $(\mathrm{N}+)$ did not raise the respiration rate and no significant interaction was observed for the addition of carbon and nitrogen (repeated measures two-way ANOVA, $P>0.05$ ).

\section{Changes in PLFA contents after the addition of carbon and nitrogen}

For all soil samples, the TotPLFAs content and the PLFA composition in the control treatment did not change significantly throughout the incubation period (one-way ANOVA, $P>0.05$; Fig. 3). The TotPLFAs content for site E on day 2 was $31 \mathrm{nmol} \mathrm{g}^{-1}$, which was lower than the TotPLFAs in the mineral and organic soils from site $\mathrm{L}$ (211 and $1013 \mathrm{nmol} \mathrm{g}^{-1}$, respectively). However, if TotPLFA contents are compared on a unit per gram of soil organic matter (SOM) basis instead of per gram of soil, the TotPLFAs from site E, from mineral soil from site L and from organic soil from site L would be 2.2, 1.6 and

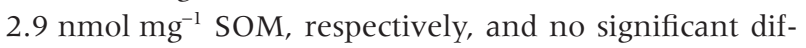
ference would be inferred (one-way ANOVA, $P>0.05$ ). The respective PLFA compositions of control treatments 
Figure 3 Effects of the addition of glucose $(\mathrm{C}+)$ and ammonium nitrate $(\mathrm{N}+)$ on the total phospholipid fatty acids content (TotPLFAs) of (a) site $E$, (b) mineral soil from site $L$ and (c) organic soil from site L. Vertical bars represent $\pm \operatorname{SE}(n=3)$.
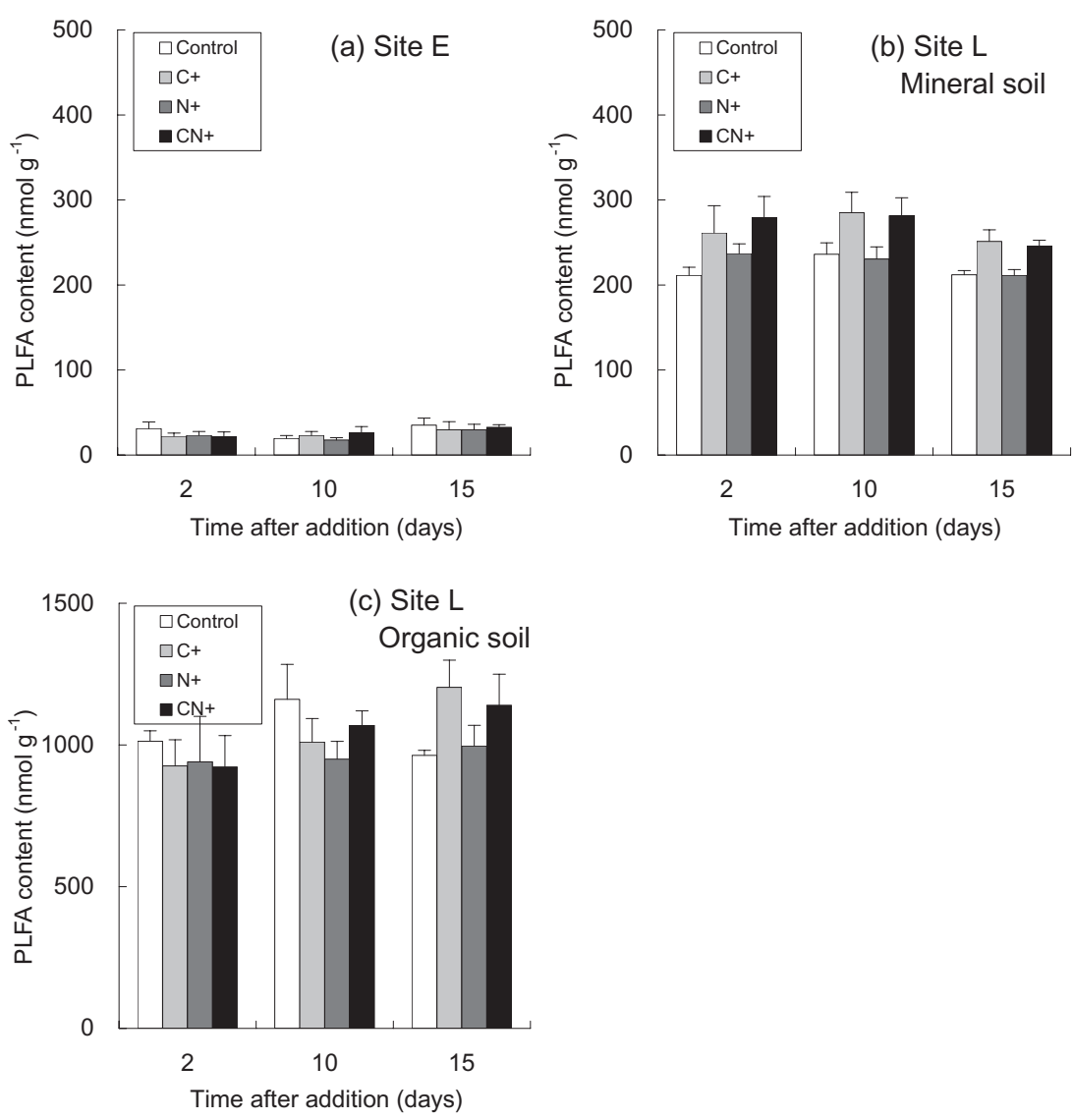

were also different among study sites: the proportion of branched chain fatty acids at site E was lower than the proportion found in the mineral and organic soils of site $\mathrm{L}$; the organic soil from site $\mathrm{L}$ had a higher proportion of unsaturated fatty acids than the levels found in the other two soils.

In site $\mathrm{E}$, throughout the incubation period, no significant differences were detected in the TotPLFA contents among treatments (Tukey-Kramer test, $P>0.05$; Fig. 3a). In mineral soil from site $\mathrm{L}$, the TotPLFA content of soils with added carbon $(\mathrm{C}+$ and $\mathrm{CN}+)$ were slightly higher than the TotPLFA content of the control (Fig. 3b). However, no significant differences were detected in the TotPLFA content between the treatments (Tukey-Kramer test, $P>0.05)$. In addition, in organic soil from site $\mathrm{L}$ the addition of carbon and/or nitrogen did not alter the TotPLFA content significantly (Tukey-Kramer test, $P>0.05$; Fig. 3c).

In most cases, the addition of carbon and/or nitrogen had little effect on PLFA composition. At site E, however, the proportion of unsaturated fatty acids in soils with both carbon and nitrogen added $(\mathrm{CN}+)$ was slightly higher than that in the control on day 15 (Tukey-Kramer test, $P<0.05)$. Furthermore, in mineral and organic soils from site L, similar differences were observed on day 10 (Tukey-Kramer test, $P<0.05$ ). In addition, in organic soil from site $\mathrm{L}$, the proportion of branched chain fatty acids in the $\mathrm{C}+$ and $\mathrm{CN}+$ treatments was significantly lower than that of the control on day 10 (Tukey-Kramer test, $P<0.05)$.

\section{Discussion}

The microbial respiration rates of the mineral soil in the early stage of primary succession (site E) in a glacier foreland in Ny-Ålesund were lower than the respiration rates in the late stage of succession (site $\mathrm{L}$ ). The respiration rate of untreated soil from site $\mathrm{E}\left(1.0 \mu \mathrm{g} \mathrm{CO}_{2}-\mathrm{C} \mathrm{g}^{-1} \mathrm{~h}^{-1}\right)$ was similar to values reported previously from that site (Bekku, Nakatsubo et al. 2004), from other glacier foreland areas (Schipper et al. 2001) and from a cold Antarctic desert (Ino et al. 1980).

The respiration responses to the addition of carbon and nitrogen were different between the early and late stages of succession, and between organic and mineral soils. In the early stage of primary succession in a High Arctic glacier foreland (site E), single additions of carbon $(\mathrm{C}+)$ and nitrogen $(\mathrm{N}+)$ had little effect on the microbial 
respiration rate (Fig. 2a). In contrast, the respiration rate of soils with both carbon and nitrogen $(\mathrm{CN}+)$ added increased for about 15 days. These results suggest that heterotrophic microbial activity (soil respiration rate) in the early stage of primary succession in a High Arctic glacier foreland is limited by twin deficiencies of carbon and nitrogen. Previous studies reported that carbon was the primary limiting factor of microbial activity and/or growth, and that nutrients such as nitrogen and phosphorus were co-limiting factors in many ecosystems ranging from Arctic tundra to tropical forests (Michelsen et al. 1999; Schmidt et al. 2000; Ekblad \& Nordgren 2002; Sørensen et al. 2006; Tekley et al. 2006). In this study, however, no significant difference in the microbial respiration was detected between the $\mathrm{C}+$ and control samples, although the mean value of respiration rate in the $\mathrm{C}+$ treatment was slightly higher than that in the control (Fig. 2a). Therefore, it was difficult to determine whether carbon was the primary limiting factor of microbial activity in the early stage of primary succession.

In the mineral soil of site $\mathrm{L}$, the addition of carbon $(\mathrm{C}+)$ alone as well as the addition of both carbon and nitrogen $(\mathrm{CN}+)$ increased the microbial respiration rate significantly (Fig. 2b). That is, the addition of glucose stimulated the respiration rate of the mineral soil from site $\mathrm{L}$ despite the fact that the soil possessed substantial concentrations of total carbon (Table 1). This fact suggests that the respiration rate was limited primarily by a deficiency of a labile carbon substrate. A considerable fraction of heterotrophic respiration is thought to arise from the decomposition of an active but small labile carbon pool (Townsend et al. 1997; Biasi et al. 2005). Smith (2005) also reported this type of limitation of the soil microbial respiration rate in a sub-Antarctic ecosystem. Interaction between carbon and nitrogen was observed in this study, indicating that nitrogen availability in the mineral soil from site L was also insufficient to utilize the added labile carbon source.

In contrast, for the organic soil of site L, neither the addition of nitrogen alone $(\mathrm{N}+)$ nor the addition of nitrogen and carbon in combination $(\mathrm{CN}+$, for an interactive effect) showed any effect on the microbial respiration rate (Fig. 2c), suggesting that the rate was not limited by nitrogen availability. In contrast, the addition of carbon $(\mathrm{C}+$ and $\mathrm{CN}+)$ also triggered a significant increase in the microbial respiration rate in the organic soil from site L, indicating that the microbial respiration rate in the organic soil of site L was also limited by labile soil carbon. However, the response pattern observed in organic soil differed somewhat from that in mineral soil; the rates of increase in carbon addition were much higher in the organic soil and a gradual decrease in the respiration rate was observed at 5-15 days after treatment. This decrease was attributable to the consumption of an additional substrate by soil microbes. In the organic soil from site L, the quantities of excess carbon emitted as $\mathrm{CO}_{2}$ from $\mathrm{C}+$ and $\mathrm{CN}+$ soils from 2 to 15 days after treatment, as calculated by subtracting the quantity of $\mathrm{CO}_{2}-\mathrm{C}$ in the control from the $\mathrm{CO}_{2}-\mathrm{C}$ in the $\mathrm{C}+$ and $\mathrm{CN}+$ treatments, were 7.6 and $6.0 \mathrm{mg} \mathrm{g}^{-1}(191 \%$ and $150 \%$ of the carbon added), respectively (calculated from data shown in Fig. 2c). We conclude, therefore, that a large proportion of the carbon from glucose was consumed by 15 days after the treatment. In addition, these results might indicate that the treatment of a labile carbon substrate promoted the utilization of a native carbon substrate.

In contrast to the respiration rate, the microbial biomass was not affected significantly by the addition of either carbon or nitrogen, or by the addition of both (Fig. 3). The increase in respiration rates without the increase in microbial biomass indicates changes in the physiological activities of microbial communities such as enzymatic activity. Both in short-term and the long-term experiments, the addition of organic matter often engenders increased enzyme activities (Kandeler et al. 1999; Crecchio et al. 2001; Marschner et al. 2003). In addition, Joergensen \& Scheu (1999) suggested that the ratio between the active and the dormant parts of the microbial biomass was changed either by the activation of dormant microorganisms or by a change in their metabolic activity after treatment. In this study a small shift in the microbial community structure was observed, which might also affect the respiration rate without increasing microbial biomass.

The insensitivity of microbial growth to the addition of carbon and/or nitrogen observed in this study was different from the result reported for a solfatara field surrounding a fumarole (volcanic vent) (Yoshitake et al. 2007). In the solfatara field, the addition of similar quantities of carbon and/or nitrogen as those used in this study triggered a remarkable two-three-fold increase in the microbial biomass during a 15 -day incubation at $25^{\circ} \mathrm{C}$ (Yoshitake et al. 2007). However, this insensitivity of microbial growth to the addition of carbon and/or nitrogen does not necessarily contradict the importance of SOM for the microbial biomass in the High Arctic. In this study, the values of TotPLFAs/SOM were similar, irrespective of the successional stage, suggesting that SOM is an important factor for determining the soil microbial biomass. Therefore, the accumulation of SOM through successional progress would engender an increase in the microbial biomass.

In conclusion, although the microbial respiration rate in the High Arctic glacier foreland that we studied was limited by carbon and nitrogen availability, the extent of that limitation differed among successional stages and 
between organic and mineral soils. Especially in the early stage of primary succession, low availabilities of both carbon and nitrogen were important limiting factors of the microbial respiration rate.

\section{Acknowledgements}

We thank Mr Y. Mouri, of the Natural Science Center for Basic Research and Development (N-BARD), Hiroshima University, for measuring the carbon and nitrogen contents of samples. This study was supported by a Grant-inAid for Scientific Research of the Japan Society for the Promotion of Science.

\section{References}

Aikio S., Väre H. \& Strömmer R. 2000. Soil microbial activity and biomass in the primary succession of a dry heath forest. Soil Biology and Biochemistry 32, 1091-1100.

Allen A.S. \& Schlesinger W.H. 2004. Nutrient limitations to soil microbial biomass and activity in loblolly pine forests. Soil Biology and Biochemistry 36, 581-589.

Arao T., Okano S. \& Nishio T. 2001. Comparison of bacterial and fungal biomass determined by phospholipid fatty acid and direct microscopical analysis in 4 types of upland soils. Soil Microorganisms 55, 29-36.

Bekku Y., Koizumi H., Oikawa T. \& Iwaki H. 1997. Examination of four methods for measuring soil respiration. Applied Soil Ecology 5, 247-254.

Bekku Y., Kume A., Nakatsubo T., Masuzawa T., Kanda H. \& Koizumi H. 1999. Microbial biomass in relation to primary succession on Arctic deglaciated moraines. Polar Bioscience 12, 47-53.

Bekku Y.S., Kume A., Masuzawa T., Kanda H., Nakatsubo T. \& Koizumi H. 2004. Soil respiration in a High Arctic glacier foreland in Ny-Ålesund, Svalbard. Polar Bioscience 17, 36-46.

Bekku Y.S., Nakatsubo T., Kume A. \& Koizumi H. 2004. Soil microbial biomass, respiration rate, and temperature dependence on a successional glacier foreland in Ny-Ålesund, Svalbard. Arctic, Antarctic, and Alpine Research 36, 395-399.

Biasi C., Rusalimova O., Meyer H., Kaiser C., Wanek W., Barsukov P., Junger H. \& Richter A. 2005. Temperaturedependent shift from labile to recalcitrant carbon sources of arctic heterotrophs. Rapid Communications in Mass Spectrometry 19, 1401-1408.

Bligh E.G. \& Dyer W.J. 1959. A rapid method of total lipid extraction and purification. Canadian Journal of Biochemistry and Physiology 37, 911-917.

Crecchio C., Curci M., Mininni R., Ricciuti P. \& Ruggiero P. 2001. Short-term effects of municipal solid waste compost amendments on soil carbon and nitrogen content, some enzyme activities and genetic diversity. Biology and Fertility of Soils 34, 311-318.

Ekblad A. \& Nordgren A. 2002. Is growth of soil microorganisms in boreal forests limited by carbon or nitrogen availability? Plant and Soil 242, 115-122.
Federle T.W. 1986. Microbial distribution in soil-new techniques. In F. Megusar \& M. Gantar (eds.): Perspectives in microbial ecology. Pp. 493-498. Ljubljana: Slovene Society for Microbiology.

Frostegård Å., Tunlid A. \& Bååth E. 1991. Microbial biomass measured as total lipid phosphate in soils of different organic content. Journal of Microbiological Methods 14, 151-163.

Frostegård Å., Tunlid A. \& Bååth E. 1993. Phospholipid fatty acid composition, biomass, and activity of microbial communities from two soil types experimentally exposed to different heavy metals. Applied and Environmental Microbiology 59, 3605-3617.

Hodkinson I.D., Coulson S.J. \& Webb N.R. 2003. Community assembly along proglacial chronosequences in the High Arctic: vegetation and soil development in north-west Svalbard. Journal of Ecology 91, 651-663.

Ino Y., Oshima Y., Kanda H. \& Matsuda T. 1980. Soil respiration in the vicinity of Syowa Station, Antarctica 1. Relationships between soil respiration rate and water content or nitrogen content. Antarctic Record 70, 31-39.

Jenkinson D.S. \& Ladd J.N. 1981. Microbial biomass in soil: measurement and turnover. In E.A. Paul \& J.N. Ladd (eds.): Soil biochemistry. Pp. 415-471. New York: Marcel Dekker.

Joergensen R.G. \& Scheu S. 1999. Response of soil microorganisms to the addition of carbon, nitrogen and phosphorus in a forest Rendzina. Soil Biology and Biochemistry 31, 859866.

Jones G.A. \& Henry G.H.R. 2003. Primary plant succession on recently deglaciated terrain in the Canadian High Arctic. Journal of Biogeography 30, 277-296.

Kandeler E., Stemmer M. \& Klimanek E.M. 1999. Response of soil microbial biomass, urease and xylanase within particle size fractions to long-term soil management. Soil Biology and Biochemistry 31, 261-273.

Kume A., Nakatsubo T., Bekku Y. \& Masuzawa T. 1999: Ecological significance of different growth forms of purple saxifraga, Saxifraga oppositifolia L., in the High Arctic, NyÅlesund, Svalbard. Arctic, Antarctic, and Alpine Research 31, 27-33.

Marschner P., Kandeler E. \& Marschner B. 2003. Structure and function of the soil microbial community in a long-term fertilizer experiment. Soil Biology and Biochemistry 35, 453461.

Minami Y. \& Kanda H. 1995. Bryophyte community dynamics on moraine at deglaciated Arctic terrain in Ny-Ålesund, Spitsbergen (in Japanese with English summary). Proceedings of the Bryological Society of Japan 6, 157-161.

Michelsen A., Graglia E., Schmidt I.K., Jonasson S., Sleep D. \& Quarmby C. 1999. Differential responses of grass and a dwarf shrub to long-term changes in soil microbial biomass C, N and P following factorial addition of NPK fertilizer, fungicide and labile carbon to a heath. New Phytologist 143, 523-538.

Nakatsubo T., Bekku Y., Kume A. \& Koizumi H. 1998. Respiration of the belowground parts of vascular plants: its contribution to total soil respiration on a successional glacier foreland in Ny-Ålesund, Svalbard. Polar Research 17, 53-59. 
Nakatsubo T., Bekku Y.S., Uchida M., Muraoka H., Kume A., Ohtsuka T., Masuzawa T., Kanda H. \& Koizumi H. 2005. Ecosystem development and carbon cycle on a glacier foreland in the High Arctic, Ny-Ålesund, Svalbard. Journal of Plant Research 118, 173-179.

Okitsu S., Sawaguchi S., Hasegawa H. \& Kanda H. 2004. Vegetation development on the glacier moraines in Oobloyah Valley, Ellesmere Island, High Arctic Canada. Polar Bioscience 17, 83-94.

Olsen S.R. \& Sommers L.E. 1982: Phosphorous soluble in sodium bicarbonate. In: A.L. Page et al. (eds.): Methods of Soil Analysis, Part 2, Chemical and Microbiological Properties. 2nd edn. Pp. 421-422. Madison, WI: American Society of Agronomy.

Osono T., Mori A., Uchida M. \& Kanda H. 2006. Chemical property of live and dead leaves of tundra plant species in Oobloyah Valley, Ellesmere Island, High Arctic Canada. Memoirs of National Institute of Polar Research, Special Issue 59, 144-155.

Paul E.A., Harris D., Klug M.J. \& Ruess R.W. 1999. The determination of microbial biomass. In: G.P. Robertson et al. (eds.): Standard soil methods for long-term ecological research. Pp. 291-317. New York: Oxford University Press.

Peacock A.D., Mullen M.D., Ringelberg D.B., Tyler D.D., Hedrick D.B., Gale P.M. \& White D.C. 2001. Soil microbial community responses to dairy manure or ammonium nitrate applications. Soil Biology and Biochemistry 33, 10111019.

Schaeffer S.M., Billings S.A. \& Evans R.D. 2003. Responses of soil nitrogen dynamics in a Mojave Desert ecosystem to manipulations in soil carbon and nitrogen availability. Oecologia 134, 547-553.

Schipper L.A., Degens B.P., Sparling G.P. \& Duncan L.C. 2001: Changes in microbial heterotrophic diversity along five plant successional sequences. Soil Biology and Biochemistry 33, 2093-2103.

Schmidt I.K., Ruess L., Bååth E., Michelsen A., Ekelund F. \& Jonasson S. 2000: Long-term manipulation of the microbes and microfauna of two subarctic heaths by addition of fungicide, bactericide, carbon and fertilizer. Soil Biology and Biochemistry 32, 707-720.
Smith V.R. 2005. Moisture, carbon and inorganic nutrient controls of soil respiration at a sub-Antarctic island. Soil Biology and Biochemistry 37, 81-91.

Sørensen L.I., Holmstrup M., Maraldo K., Christensen S. \& Christensen B. 2006. Soil fauna communities and microbial respiration in High Arctic tundra soils at Zackenberg, Northeast Greenland. Polar Biology 29, 189-195.

Stoffel W., Chu F. \& Ahrens Jr E.H. 1959. Analysis of long-chain fatty acids by gas-liquid chromatography. Micromethod for preparation of methyl esters. Analytical Chemistry 31, 307-308.

Svoboda J. \& Henry G.H.R. 1987. Succession in marginal Arctic environments. Arctic and Alpine Research 19, 373-384.

Teklay T., Nordgren A. \& Malmer A. 2006. Soil respiration characteristics of tropical soils from agricultural and forestry land-uses at Wondo Genet (Ethiopia) in response to C, N and P amendments. Soil Biology and Biochemistry 38, 125-133.

Townsend A.R., Vitousek P.M., Desmarais D.J. \& Tharpe A. 1997. Soil carbon pool structure and temperature sensitivity inferred using $\mathrm{CO}_{2}$ and ${ }^{13} \mathrm{CO}_{2}$ incubation fluxes from five Hawaiian soils. Biogeochemistry 38, 1-17.

Uchida M., Muraoka H., Nakatsubo T., Bekku Y., Ueno T., Kanda H. \& Koizumi H. 2002. Net photosynthesis, respiration, and production of the moss Sanionia uncinata on a glacier foreland in the High Arctic, Ny-Ålesund, Svalbard. Arctic, Antarctic, and Alpine Research 34, 287-292.

Vance E.D. \& Chapin III, F.S. 2001. Substrate limitations to microbial activity in taiga forest floors. Soil Biology and Biochemistry 33, 173-188.

White D.C., Davis W.M., Nickels J.S., King J.D. \& Bobbie R.J. 1979. Determination of the sedimentary microbial biomass by extractable lipid phosphate. Oecologia 40, 51-62.

Yoshitake S., Sasaki A., Uchida M., Funatsu Y. \& Nakatsubo T. 2007. Carbon and nitrogen limitation to microbial respiration and biomass in an acidic solfatara field. European Journal of Soil Biology 43, 1-13.

Yoshitake S., Uchida M., Nakatsubo T. \& Kanda H. 2006. Characterization of soil microflora on a successional glacier foreland in the High Arctic on Ellesmere Island, Nunavut, Canada using phospholipid fatty acid analysis. Polar Bioscience 19, 73-84. 